\title{
强化施工安全管理 保证安全施工
}

林德鹤

福建省闽南建筑工程有限公司

DOI:10.32629/btr.v2i3.1984

[摘 要] 我国建筑市场的繁㭉促进了我国经济发展的同时也对建筑施工企业提出了更高的要求。建筑施工企业必须通过加 强自身建设, 以保障建筑工程施工质量为目标, 运用现代管理理念进行建筑工程施工管理。通过施工管理工作的科学进行促进 建筑工程质量管理工作的开展, 促进工程施工成本控制的有效实施。

[关键词] 建筑施工管理; 安全管理; 质量管理

建筑施工管理一直以来都被认为是一个粗放的状态, 而 施工安全管理也一直大部分靠管理者主观意识及行为, 因此, 在施工现场施行标准化管理是当务之急, 也是对传统建筑行 业的一次革新, 这对本行业的发展来说有着重要意义。

\section{1 安全质量标准化的定义}

全质量标准化工作的具体定义就是在企业生产经营和 全部活动中, 全面贯彻执行国家、地区、行业颁发的各项规 程、规章、标准, 按标准组织生产经营活动, 按标准从事各项 管理工作, 按标准进行作业和工作, 按标准对企业各个环节 进行持续改进和自我完善。具体到一个企业来说, 就是要结 合企业实际情况, 建立适合于本企业的科学合理的一系列执 行标准以及规章制度及相应目标, 使企业的所有活动都能按 照统一的标准来执行, 并在科学有效的指导和约束下, 充分 保证工作质量, 最终全面提升企业的竞争力。

安全质量标准化具体来说就是将标准化工作引入到安 全工作中来, 对于一个建筑施工企业来说, 安全工作是一切 工作的重中之重, 而将其标准化, 对于企业的经营管理来说 无疑是大有禆益的。因此, 企业员工务必要自觉贯彻执行相 关标准化政策以及具体的规章制度, 相关管理人员务必将指 导和督察工作做到位, 使安全质量标准化工作真正落到实处, 并在具体实践中不断改进, 使其成为一个操作性强、效率高 的好的体制, 全面提高企业的效率及质量。

2 建筑工程施工安全管理与质量管理的科学实施

2.1 施工安全管理重要性及其实施

施工安全管理是保障施工人员安全的关键, 是实现施工
过程成本控制的重要组成部分, 其安全管理工作的科学开展 不仅能够有效保障施工人员的人身安全, 同时也能够减少由 于安全事故造成的成本增加。建筑施工安全设施是有施工企 业自行购置的设施, 分包商往往会为了减少安全设施的投入 使用, 没有进行安全防护设备的添置与维护, 造成施工现场 安全防护设施缺损, 埋下施工安全隐患。针对这样的情况, 建筑施工企业必须以加强分包商管理为基础开展施工过程 的安全管理工作。根据建筑工程施工特点, 对施工过程的楼 梯口、电梯口、预留洞口、出入口, 沟、坑、槽和深基础周 边、楼层周边、楼梯侧边、平台或阳台边、屋面周边, 机具、 车辆、暂设电器、高温、高压容器等进行严格的安全防护设 备检查, 确保安全方式设施的完好, 保障建筑工程施工过程 人员、设备的安全。

以基础安全防护设施的管理保障施工安全的同时, 施工 企业还要加强施工人员安全意识的培养。在工程施工前对施 工人员进行安全意识培养、提高施工人员的安全意识, 促进 建筑工程施工安全管理的有效实施。施工企业还要加强岗位 标准操作规程的完善, 并注重施工过程的检查, 确保施工过 程严格按照标准操作进行, 减少安全事故发生的可能。对于 施工过程的设备操作, 要严格执行非操作人员严禁操作设备 的规定, 避免由于非操作人员进行操作造成的人员伤亡。同 时也减少非操作人员操作造成的设备损伤等。另外建筑施工 企业还要加强施工设备的管理, 对起重设备进行严格的登 记、验收、检测, 保障起重机械等特殊设备的强度复核施工 要求。对于自行搭建的脚手架等也要进行严格测试, 确保其
度等问题进行控制, 保证浇筑效果。待混凝土强度达到要求 后进行拆模, 拆模时, 工作人员需要小心, 减少因疏忽造成的 混凝土表面或棱角损坏情况。

\section{5 结束语}

综上所述, 变形缝的合理设置可以提高房建施工质量, 保证房建结构稳定, 因此, 在实际施工中, 施工人员应加强对 此方面的重视, 掌握技术要点, 进而保证施工质量。

\section{[参考文献]}

[1]许小英.关于房建施工结构变形缝的施工工艺分析
及其技术研究[J].福建建材,2017(11):85-86.

[2]杨震. 关于房建施工结构变形缝的施工工艺与技术的 分析[J].居舍,2018(27):58-59.

[3]宋跃鸣. 论述房建施工结构变形缝的施工工艺与技术 [J].科技创业家,2014(08):53.

作者简介：

覃家琨, (1987--), 男, 广西南宁人, 壮族, 本科学历, 从事土 木工程管理。 
强度能够满足施工需要, 保障工程施工人员的安全。

2.2 施工质量管理重要性及其实施

建筑工程施工质量是企业生存的根本, 对建筑工程施 工企业有着重要的影响。随着现代建筑质量要求以及有关 规定的不断完善, 建筑工程施工企业对施工质量的认识也 不断提高。为了更好的实现建筑工程施工质量管理工作, 工程施工企业必须构建完善的质量管理体系, 针对建筑工 程实际情况以及企业设备、技术、人员情况等构建适合企 业管理流程的质量管理体系, 促进施工质量管理工作的开 展。针对影响建筑工程施工质量的因素, 其施工质量控制与 管理主要分为人员管理、材料管理、机械设备管理以及施 工技术管理几方面。人员管理是保障施工质量的基础, 其对 施工质量有着重要的影响。建筑工程施工企业要加强施工 技术人员专业技术培养以及管理人才的管理能力培养, 以 此加钱施工过程人为因素的控制, 提高建筑工程施工质量。 针对建筑施工材料对建筑工程重要的影响, 施工企业要以 严格的进场管理、存放管理以及使用前的检验做好施工材 料的管理工作, 保障施工用材料符合施工要求, 保障施工 质量。

2.3 完善企业自身的评价体系, 促进施工安全管理与施 工质量管理的实施

针对建筑工程分包的实际情况, 建筑工程施工企业要 构建完善的施工评价体系, 对分包企业安全管理情况、施工 质量管理情况的进行系统的评测, 以此为施工过程的安全 管理实施与质量管理工作开展奠定基础。同时施工企业还 要加强施工过程中对分包企业施工过程的管理, 以中标企 业为中心对分包企业进行全面的安全管理检查与质量管理 监督, 有效保障建筑工程施工过程安全管理与质量管理的 实施。

\section{3 对建筑施工质量安全标准化实施}

在具体实施上, 要务必做到安全生产管理、施工现 场、人员操作和监督检查等等各项任务标准化的要求, 具 体如下:

3.1 标准化要求务必要做到全员深刻认识并严格执行, 即使是在生产服务的辅助过程, 也要全面推行安全标准化建 设, 检验事先制定的标准是否符合实际。

3.2 对在生产中使用的有害物料、有害物质、危险设备 和装置、危险工序等必须实行标准化管理, 抓住事故的关键。

3.3 加强监督检查, 对每个生产岗位、每道操作程序和 每个人的操作行为以及安全管理的过程进行经常性的检查, 及时发现实施中的偏差和问题。

\section{4 结束语}

综上所述, 现代建筑工程施工管理工作中的安全管理与 质量管理是施工管理的两大重点, 其对建筑施工企业有着重 要的影响。现代建筑施工企业必须认识到施工管理工作的重 要性, 以企业的重视为基础, 加强企业施工管理体系的建立 与完善, 加强企业安全设施与质量管理投入, 促进企业安全 管理与质量管理水平的提高, 促进建筑施工管理工作的开展, 以此提高企业的综合管理能力、提高企业的市场竞争力, 促 进建筑工程施工企业的健康发展。

[参考文献]

[1]徐健.建筑工程管理及施工质量控制 [J].住宅与房地 产,2018(34):110.

[2]郝星先.加强建筑工程施工安全管理的办法[J].中华 建设,2018(10):76-77.

[3]刘洁.建筑工程土建施工现场管理的优化对策[J].居 舍,2019(04):125. 